\title{
Antimicrobial and Antioxidant Properties of Marjoram (Origanum Marjorana, Lamiacae) Essential Oil.
}

Islam M. H. Rizk ${ }^{1 \star}$, Mohamed M. M. Amaar², Ibraheim A. Ibraheim³ and Abdel-Hameed M. Othman ${ }^{1}$

1 Department of Environmental Biotechnology, Genetic Engineering and Biotechnology Research Institute, The University of Sadat city, Sadat city, Egypt, Box-79

${ }^{2}$ Department of Agricultural Botany, Faculty of Agriculture, Minufiya University, Egypt.

${ }^{3}$ Department of Plant Biotechnology, Genetic Engineering and Biotechnology Research Institute, The University of Sadat city, Egypt, Box-79

*Corresponding Author; Email: islam rizk2@yahoo.com.

\section{ABSTRACT}

Marjoram oil relaxes tense muscles and is supportive of the nervous and cardiovascular systems. It is antispasmodic and tonic. In this study, the essential oil of marjoram was analyzed by gas chromatography and assayed for their antimicrobial and antioxidant activity. Antimicrobial activity was tested against Fusarium aquaductuum and fusarium dimerum isolate (1), at 1.5, 3 and 4.5 concentration. A significant rate of antifungal activity noticed at $4.5 \%$ concentration of oil. Antioxidant activity was noticed when the oil gave good result and more active on intestine cancer.

Keywords: Marjoram, essential oil, Antioxidant, Gas chromatography, Antimicrobial.

\section{INTRODUCTION}

Origanum/marjoram species have been reported to show significant antimicrobial activity and its prolonged use may reduce gut bacteria (Meschino, 2005; Hazzit et al., 2006; Leeja and Thoppil, 2007). Marjoram oil was found effective against Beneckea natriegens, Erwinia carotovora, and Moraxella species. It also affected the growth of Staphylococcus aureus and Aspergillus niger (Deans and Svoboda, 1990). The emulsified oil of marjoram was reported to possess strong antiparasitic activity (Force et al., 2000). Marjoram was also found effective against food-borne pathogens and spoilage bacteria in minced meat (Dragland et al., 2003; Barbosa et al., 2009). Marjoram is also added to mouth rinse and its cures inflamed skin wounds and infections (Bremness 1994; McCarroll et al., 2008; Suntar et al., 2011). Fresh as well as dry marjoram is one of the most popular culinary herbs. It is used globally in salad, meat and vegetable dishes for flavor and as a natural antioxidant to avoid the use of synthetic antioxidants in food (Arts and Hollman, 2005; Shan et al., 2005; D'Antuono and Elementi, 2006; Yanishlieva et al., 2006; Hossain et al., 2008; Machado et al., 2010).

Mohamed and Mansour, 2012, studied the effect of addition of essential oils of marjoram (Origanum marjorana L.) to beef patties formulated mechanically deboned poultry meat (MDPM). Overall, the study 
indicated the potential use of natural herbal essential oils to protect against lipid oxidation and improve the sensory attributes of beef patties formulated with MDPM.

Brunison, et al., 2011, studied the optimization of the accelerated solvent extraction (ASE) conditions to maximize the antioxidant capacity of the extract from marjoram.

Żegarska, et al., 2009 studied the phenolic compounds extracted from marjoram (Origanum majorana L.) with $95 \%$ ethanol. A number of antioxidant and radical-scavenging capacity tests were performed on the prepared extracts using colorimetric assays and model system studies.

The aim of the present study was to extract marjoram essential oil from biologically control marjoram plants. Gas chromatographic analysis of marjoram oil was proved the chemical structure of oil. Cell Lines study for carcinoma of liver, intestinal and prostate were carried out.

\section{MATERIAL AND METHODS}

\section{Separation of marjoram oil.}

The fresh marjoram plants were cut into small pieces, which transferred into tube. Marjoram tubes were then taken from the field and back to the marjoram distillery where the oil will be extracted. Steam works its way through the marjoram plants vaporizing the oil from leaves and taking it to the top of the tube. The oil and water vapor then exits the tub and flows to the condenser tanks, which are full of cool water. The vapor runs through a series of tubes called the condenser and is eventually turned back into a liquid. The liquid comes out bottom of the condenser and into a tank called the separator. In the separator the oil floats to the top because it is lighter than the water maker comparison between the oil compounds was achieved using gas chromatography (GC) technique.

\section{Separation conditions of essential oils.}

Instrument : Gas Liquid Chromatography/ Unicam PRO- GC

COLUMN: 3\% OV-17 (Methyl phenyl Silicone) on Chromosorb-WHP.
Mesh: 100-120; Dimensions: $1.5 \mathrm{x}$ $4 \mathrm{~mm}$; Temperature Programing: Initial Temp. $70 \stackrel{\circ}{\circ}$; Initial Time. $5 \mathrm{~min}$; Rate. $8 \stackrel{\circ}{\circ} \mathrm{C} / \mathrm{min}$; Final Temp. $200 \stackrel{\circ}{\circ}$; Final

Time. $40 \mathrm{~min}$; Injector. $250{ }^{\circ} \mathrm{C}$; Detector $300 \stackrel{\circ}{\circ}$. Gases Flow Rate: $\mathrm{N}_{2} .30 \mathrm{ml} / \mathrm{min} ; \mathrm{H}_{2}$. $33 \mathrm{ml} / \mathrm{min}$;

Air. $330 \mathrm{ml} / \mathrm{min}$.

\section{Effect of marjoram oil on the growth} of pathogenic fungi.

Different concentrations of marjoram oil i.e., $1.5 \%, 3 \%$ and $4.5 \%$ were prepared in PDA medium. Either Fusarium aquaeductuum or Fusarium dimerum $(A)(6 \mathrm{~mm}$ in diameter) was put in the middle of each Petri dish. Control dishes included PDA medium only and three dishes were used as replicates for each treatment. All dishes were incubated at $25^{\circ} \mathrm{C}$ until the control dish was full with each fungal growth.

\section{Biological tests}

Potential cytotoxicity of marjoram oil was tested using the method of Skehan et al. (1990). Cells were plated in 96-multiwell plate 
(10 cells/well) for $24 \mathrm{hrs}$ before treatment with the compound(s) to allow attachment of cell to the wall of the plate. Different concentration of the tested oil $(0,1,2,5$ and 10 were added to the cell. Monolayer triplicate wells were prepared for each individual dose. Monolayer cells were incubated with four concentrations for $48 \mathrm{hrs}$ at $37 \circ \mathrm{C}$ and in atomosphere of $5 \%$ CO2. $\mu \mathrm{g} / \mathrm{ml})$. After 48hrs, cells were fixed, washed and stained with Sulfo-RhodamineBstain. Excess stain was washed with acetic acid and attached. The relation between surviving fraction and drug concentration plotted to get the survival curve of each tumor cell line after the specified compound recovered with Tris-EDTA buffer. Color intensity was measured in an ELISA reader.

\section{RESULTS}

\section{Fungicidal effect of marjoram oil.}

Marjoram oil at the concentration of 1.5, 3 and $4.5 \%$ was tested against either Fusarium aquaeductuum or Fusarium dimerum $(B)$ on PDA medium. Results in Table (1) and Figure (1\&2) clear that the marjoram oil at all tested concentrations significantly reduced the growth of both pathogens growth reduction of F.aquaeductuum was increased from 3.87 to 2.23 respectively at $1.5 \%$ and $4.5 \%$ marjoram oil concentration reduction of F.dimerum (B) growth from $4.03,3.00$ and 2.20 at $1.5,3$ and $4.5 \%$ respectively.

Table (1): Effect of different concentration of marjoram oil on mycelial growth of Fusarium aquaeductuum and Fusarium dimerum(B).

\begin{tabular}{|c|c|c|c|c|}
\hline $\begin{array}{c}\text { Marjoram oil } \\
\text { concentration \% }\end{array}$ & $\begin{array}{c}\text { Fusarium } \\
\text { aquaeductuum (cm) }\end{array}$ & $\mathbf{R} \%$ & $\begin{array}{c}\text { Fusarium } \\
\text { dimerum(B) (cm) }\end{array}$ & R \% \\
\hline 1.5 & 3.87 & 57 & 3.04 & 55 \\
3.0 & 3.10 & 65 & 3.00 & 66 \\
4.5 & 2.23 & 75 & 2.20 & 75 \\
\hline Control & 9 & & 9 & \\
\hline L.S.D at 5\% & 0.32 & & 0.25 & \\
\hline at 1\% & 0.4 & & 0.37 & \\
\hline
\end{tabular}




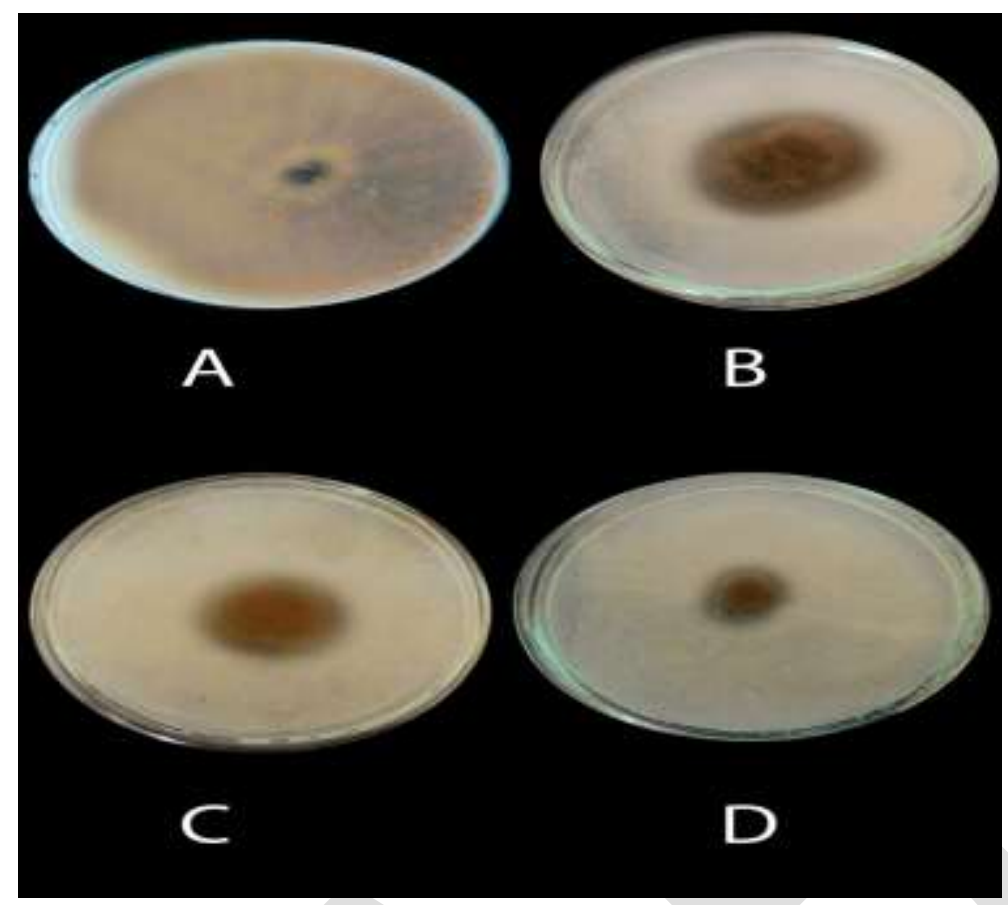

Fig. (1): Effect of different concentrations of marjoram oil in PDA medium on the growth of Fusarium aquaeductuum.
A: 0 (control);
B: $1.5 \%$;
C: $3 \%$;
D: $4.5 \%$.

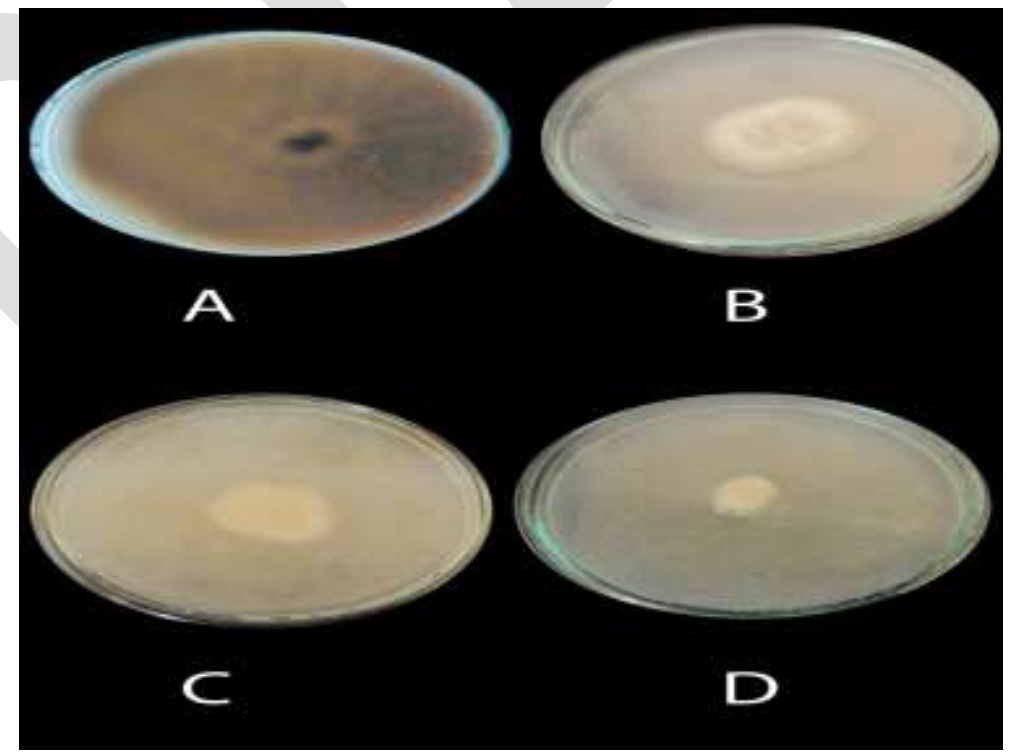

Fig. (2): Effect of different concentration of marjoram oil in PDA medium on the growth of fusarium dimarum (B).
A: 0 (Control);
B: $1.5 \%$;
C: $3 \%$;
D: $4.5 \%$. 


\section{Chemical analysis of marjoram oil}

Gas liquid chromatography analysis proved that there are 23 components in marjoram oil as shown in Table (2). All these Components were severely decreased by pathogen only (fusarium aquaeductum); except P-Cymene which showed little increase. However, the application of the biocontrol agents to the oil infested with the pathogen showed higher increase of all components than both untreated control plants and those treated with the pathogen only. In most cases; such increments were two folds of non-treated plants and three folds of those suffered from the pathogen.

Table (2): Gas Chromatographic analysis of marjoram oil.

\begin{tabular}{|c|c|c|c|c|c|}
\hline \multirow[b]{2}{*}{ No } & \multirow[b]{2}{*}{ RT(min.) } & \multirow[b]{2}{*}{ Component } & \multicolumn{3}{|c|}{ Concentration (mg/ml) } \\
\hline & & & Control & $\begin{array}{c}\text { Fusarium } \\
\text { aquaeductuum }\end{array}$ & $\begin{array}{c}\text { F.aquaeductuum } \\
+ \text { B.megaterium+ } \\
\text { T.harzianum+T. } \\
\text { hamatum }\end{array}$ \\
\hline 1 & 6.981 & $\alpha-P i n e n e$ & 0.60 & 0.33 & 1.86 \\
\hline 2 & 7.109 & cis-Ocimene & 0.40 & 0.21 & 1.45 \\
\hline 3 & 7.754 & $\beta$ - Pinene & 0.75 & 0.44 & 1.75 \\
\hline 4 & 7.817 & psi-Limonene & 0.60 & 0.48 & 1.66 \\
\hline 5 & 7.983 & Myrceneß- & 0.82 & 0.57 & 2.92 \\
\hline 6 & 8.058 & Decane & 2.50 & 1.35 & 4.53 \\
\hline 7 & 8.221 & Thujene $\beta$ - & 3.73 & 1.77 & 5.63 \\
\hline 8 & 8.402 & Terpinolene & 7.24 & 3.23 & 9.24 \\
\hline 9 & 8.533 & p-Cymene & 2.64 & 3.25 & 4.85 \\
\hline 10 & 8.605 & Terpineney- & 7.25 & 4.22 & 10.25 \\
\hline 11 & 9.021 & Terpinene $\alpha$ - & 8.40 & 5.41 & 11.43 \\
\hline 12 & 9.446 & Terpinene-4-acetate & 3.11 & 2.13 & 6.12 \\
\hline 13 & 9.512 & Piperidinium,1-1-dimethyl- & 7.25 & 5.22 & 10.26 \\
\hline 14 & 10.695 & Terpinen-4-ol & 7.76 & 5.73 & 11.76 \\
\hline 15 & 10.799 & Ascorbic acid, permethyl- & 9.47 & 6.42 & 14.74 \\
\hline 16 & 10.909 & Dihydrocarveol & 0.20 & 0.14 & 0.66 \\
\hline 17 & 11.989 & D-(-)-Fractose & 0.41 & 0.32 & 0.81 \\
\hline 18 & 13.524 & Caryophyllene & 9.20 & 5.23 & 11.22 \\
\hline 19 & 14.160 & Geranyl isovalerate & 0.82 & 0.64 & 0.98 \\
\hline 20 & 16.577 & Butylated hydroxytoluene & 0.78 & 0.46 & 1.68 \\
\hline 21 & 17.167 & Sinapic acid & 0.74 & 0.53 & 1.44 \\
\hline 22 & 20.718 & Phytol & 2.10 & 1.12 & 3.40 \\
\hline 23 & 21.99 & 3,5-Dimethoxycinnamic acid & 1.98 & 0.75 & 2.28 \\
\hline
\end{tabular}

\section{Cell line Analysis}

A cell line arises from a primary culture at the time of the first successful subculture. The term cell line implies that cultures from it consist of lineages of cells originally present in the primary culture. The terms finite or continuous are used as prefixes if the status of the culture is known. A continuous cell culture is one that is apparently capable of an unlimited number of population doublings; often referred to as an immortal cell culture. Such cells may or may not express the characteristics of in vitro neoplastic or malignant transformation. A finite cell culture is capable of only a limited number of population doublings after which the culture ceases proliferation.

Cell Lines study in Table (3) clear that usage of marjoram oil are good curative for carcinoma of liver, intestinal and prostate. 
Increasing the dose from 5 to $50 \mathrm{mg} / \mathrm{ml}$ should more efficacies in all diseases. It could be also noticed that marjoram oil is more active against Intestinal and prostate carcinoma. Carcinoma of liver was decreased from 20 - $53 \%$ by increasing the oil coneen traitor from $5-50$ $\mathrm{mg} / \mathrm{ml}$. However intestinal carcinoma showed highly response to marjoram oil application; where it was decreased by about $60 \%$ even at $5 \mathrm{mg} / \mathrm{ml}$ dosage. Prostate carcinoma case was more responded by oil application which decreased by about $60 \%$ at $5 \mathrm{mg} / \mathrm{ml}$ dose and reached to $78 \%$ reduction of the disease at the cone of $50 \mathrm{mg} / \mathrm{ml}$.

\section{Table 14: Drug cytotoxicity}

(A)

\begin{tabular}{|c|c|c|c|c|}
\hline No & $\begin{array}{c}\text { Conc. } \\
\mathrm{M} / \mathbf{m l}\end{array}$ & $\begin{array}{c}\text { HEPG2- } \\
\mathrm{A}\end{array}$ & CACO-A & PC3 \\
\hline 1 & 0.0 & 1.000 & 1.000 & 1.000 \\
\hline 2 & 5.0 & 0.797 & 0.395 & 0.417 \\
\hline 3 & 12.5 & 0.633 & 0.360 & 0.282 \\
\hline 4 & 25.0 & 0.630 & 0.341 & 0.229 \\
\hline 5 & 50.0 & 0.467 & 0.352 & 0.217 \\
\hline
\end{tabular}

(B)

\begin{tabular}{|l|c|}
\hline \multicolumn{1}{|c|}{ Sample } & IC50 $\mathbf{~ m g} / \mathbf{m l}$ \\
\hline HEPG2-A & 45.20 \\
\hline CACO-A & 3.98 \\
\hline PC3 & 4.28 \\
\hline
\end{tabular}

\section{Where:}

HEPG2-A: Liver carcinoma cell line.

CACO-A: Intestinal carcinoma cell line.

PC3: Prostate carcinoma cell line.

Table 3: Drug cytotoxicity

\section{DISCUSSION}

monoterpenes which are established as antioxidants could control oxidative damage induced by ethanol toxicity to brain, liver and fertility ( Novak et al ., 2000 ; Ahme et al ., 2007 and El-Ashmawy et al ., 2007 a \& b ).
Marjoram alcoholic aqueous extracts and essential oil could protect liver and Kidney damage and lead acetate injury (El-Ashmamy et al., 2005; 2007 a\&b and Abd El-Ghany and EI-Metwally, 2010). Marjoram volatile oil contain high percentages of polyphnols and 
Marjoram species have been repoted to show significant antimicrobial activity (Meschino, 2005; Hazzit et al., 2006 and leeja and Thoppil, 2007). Marjoram oil was effective against Beneckea natriegens, Erwinia caratovora, Moraxella sp., Staphylococcus aureus and Aspergillus niger (Deans and Svoboda, 1990).

Such plant is subjected to the attack by many soil-borne diseases which affect its growth and oil quantity and quality. Fusarium aquaeductuum,

F.aquaductuum var. medium and F.dimerum colonized roots and stem bases of marjoram causing server wilt and root-rot diseases as obtained in this investigation. It is well known that F.oxysporum cause with diseases of several herbs including Japanese (Mentha arvensis haplocalyx var piperascens) as reported by Truman and Wick (1996) Sattar and Husain (1980) and Subba Rao (1981).

Marjoram oil at the concentrations of $1.5,3$ and $4.5 \%$ reduced the growth of both fusarium pathogens; significantly. This could be due to the presense of polyphenois and monoterpenes in high percentages in this oil as reported by Novek et al; 2000; armed et al., 20007 and El-Ashmamy et al., 2007 a\&b. It is of logic that increasing the used concentration of marjoram oil shall increase its toxicity efficacy; as obtained in this study.
However antimicrobial activity of marjoram oil was reported also by Masschino, 2005; Hazzit et al., 2006 and leeja and thoppil, 2007. Marjoram was initially used by Hippocrates as an antiseptic agent. It is a well Liked home remedy for chest infection, cough, throat, rheumatic pain, nervous disorders, cardiovascular diseases, epilepsy, insomnia, skin care, flatulence and stomach disorders (Bremness, 1994; Faleiro et al ; 2005; Yazdanparast and Shahriyary, 2008).

Using marjoram oil is good curative for carcinoma of liver, intestinal and prostates. Increasing the dose from $5+50 \mathrm{mg} / \mathrm{ml}$ should elliciency in all diseases. It could be also noticed that marjoram oil is more active against Intestinal and prostate care.

Marjoram alcohoholic aqueous extracts and essential oil could protect liver and kidney damage, and lead acetate injury (El-Ashmawy et al; 2005; 2007 a, b and Abd El-Ghany and El-Metwally, 2010). The antiproliferative activity of marjoram was confirmed in human lymphoblastic leukemia cell line Jurkat (Parpageorgiou et al., 2008;

Abdel-Massih et al., 2010).

The essential oil obtained from the flowering heads of marjoram has aromatic smell and contain high percentage of polyphenols and monoterpenes which are established as antioxidants (Novak et al., 2000). 


\section{REFERENCES}

Abd E.M.A and El-Metwally, N. Y. (2010). "Effect of Marjoram Leaves on Injured Liver in Experimental Rats", Report and Opinion, 2(12), 181-191.

Abdel-Massih, R.M; Fares, R.; S. Bazzi, S.; El-Chami N. and Baydoun E. (2010). "The Apoptotic and Anti-Proferative Activity of Origanum Majorana Extracts on Human Leukemic Cell Line". Leuk. Res., 34(8), 1052-1056.

Aheme, S. ;A; Kerry J. P and O'Brien, N.M. (2007). Effect of Plant Extracts on Antioxidant Status and Oxidant-Induced Stress in Caco-2 Cells. Br. J. Nutr., 97(2), 321-328.

Arts, I.C. and Hollman, P.C. (2005). "Polyphenols and Disease Risk in Epidemiologic Studies". Am. J. Clin. Nutr., 81, 317-325.

Barbosa, L.N.; Rall, V.L.; Fernandes, A.A.; Ushimaru, P,I,; Da S.P.I. and Fernandes, A. Jr. (2009). "Essential oils against foodborne pathogens and spoilage bacteria in minced meat". Food borne Pathog. Dis., 6(6), 725- 728.

Bremness, L. (1994). "The Complete Book of Herbs: A Practical Guide to Growing and Using Herbs" Fifth Edition; Studio; Seattle Goodwill, WA, USA.

Burnison B.K. (2011), "Modified Dimethyl Sulfoxide (DMSO) Extraction for Chlorophyll Analysis of Phytoplankton". Canadian Journal of Fisheries and Aquatic Sciences, 37(4). 729-733.

D'Antuono, L.F. and Elementi. S. (2006). Facts and Perspectives of Edible Lamiaceae: Flavor and Health, Industrial
Exploitation, and The Consumer. Acta Horticulturae, 723, 33-50.

Deans, S.G. and Svoboda, K.P. (1990). "The Antimicrobial Properties of Marjoram (Origanum Majorana L.) Volatile Oil". Flav. Frag. J., 5(3): $\quad$ 187-190.

Dragland, S.; Senoo, H.; Wake, K.; Holte. K. and Blomhoff, R. (2003). "Several Culinary and Medicinal Herbs are Important Sources of DietaranTioxidants". J. Nutr., 133(5): 1286-1290.

El-Ashmawy, I.M.; El-Nahas, A.F. and Salama, O.M. (2005). "Protective Effect of Volatile Oil, Alcoholic and Aqueous Extracts of Origanum Majorana on Lead Acetate Toxicity in Mice". Basic Clin. Pharmacol. Toxicol., 97(4), 238-243.

El-Ashmawy, I.M.; Amal, S. and Salama, O.M. (2007a). "Acute and Long Term Safety Evaluation of Origanum Majorana Essential Oil". Alex. J. Pharm. Sci., 21, 29-35.

El-Ashmawy IM, Saleh A, Salama OM (2007b). "Effects of Marjoram Volatile Oil and Grape Seed Extract on Ethanol Toxicity in Male Rats". Basic Clin. Pharmacol. Toxicol., 101(5): 320-327.

Faleiro, L.; Miguel, G.; Gomes, S.; Costa, L.; Venancio F, Teixeira A, CristinaFigueiredo A, Barroso JG, Pedro LG (2005)." Antibacterial and Antioxidant Activities of Essential Oils Isolated from Thymbra capitata L. (Cav.) and Origanum vulgare L"., J. Agric. Food Chem., 53(21): 8162-8168.

Force, M.; Sparks, W.S. and Ronzio, R.A. (2000)." Inhibition of Enteric Parasites 
by Emulsified Oil of Oregano in Vivo". Phytother. Res., 14(3), 213-214.

Hazzit, M.; Baaliouamer, A.; Leonor-Faleiro, M. and Graca, M.M. (2006). "Compostion of the essential oils of Thymus and Origanum species from Algeria and their antioxidant and antimicrobial activities". J. Agric. Food Chem., 54, 6314-6321.

Hossain, M.B.; Brunton, N.P.; Barry-Ryan, C.; Martin-Diana, A.B. and Wilkinson, M. (2008). "Antioxidant Activity of Spice Extracts and Phenolics in Comparison to Synthetic Antioxidants". Rasayan J. Chem., 1, 751-756.

Leeja, L. and Thoppil, J.E. (2007). "Antimicrobial Activity of Methanol Extract of Origanum Majorana L. (Sweet Marjoram)". J. Environ. Biol., 28(1), 145146.

McCarroll, N.; Keshava, N.; Cimino, M.; Chu, M.; Dearfield, K.; Keshava, C.; Kligerman, A,; Owen, R.; Protzel, A.; Putzrath, $R$. and Schoeny, $R$. (2008)."An Evaluation of The Mode of Action Framework for Mutagenic Carcinogens Case Study: Cyclophosphamide". Environ. Mol. Mutagen, 49(2), 117-131.

Machado, M.; Dinis, A.M.; Salgueiro, L.; Cavaleiro, C.; Custodio, J.B and Sousa, M.C. (2010)." Anti-Giardia Activity of Phenolic-Rich Essential Ooils: Effect of Thymbra Capitata, Origanum Virens, Thymus Zygis Subsp, Sylvestris, and Lippia Granveolens on Trophozoites Growth, Viability, Adherence, and Ultrastructure". Parasitol. Res., 106(5), 1205-1215.
Meschino, J. (2005). "Oil of Oregano: Nature's Antibiotic and Anti-Fungal Supplement". Dynamic Chiropractic Canada, 23(10), 1.

Mohamed, M.H. and Mansour H.A., (2012). "Incorporating Essential Oils of Marjoram and Rosemary in The Formulation of Beef Patties Manufactured with Mechanically Deboned Poultry Meat to Improve The Lipid Stability and Sensory Attributes". LWA-Food Science and Technology, 45, 79-87.

Novak, J.; Bitsch. C; Langbehn, J; Pank, F; Skoula, M.; Gotsiou, Y. and Franz, C.M. (2000). Ratios of Cis- and TransSabinene Hydrate in Origanum Majorana L. and Origanum Microphyllum (Bentham) Vogel Biochem. System Ecol., 28(7), 697-704.

Papageorgiou, V.; Mallouchos, A. and Komaitis, M. (2008). Investigation of The Antioxidant Behavior of Air- and Freeze-Dried Aromatic Plant Materials in Relation to Their Phenolic Content and Vegetative Cycle. J. Agric. Food Chem., 56(14), 5743-5752.

Sattar, A. and Husain, A. (1980). "Fusarium Wilt of Japanese Mint".

J. New Botanist, 7, 69-71.

Shan B, Cai YZ, Sun M, Corke H (2005)."Antioxidant Capacity of 26 Spice Extracts and Characterization of Their Phenolic Constituents". J. Agric. Food Chem., 53, 7749-7759.

Skehan, P., Strong R.,et al. (1990)." New coloremtric cytotoxicity assay for anticancer drug screening". J Natl cancer Inti. 82: 1107-1112 
Suntar, I.; Akkol, E.K.; Keles, H.; Oktem, A.;

Baser, K.H. and Yesilada E, (2011). A

Novel Wound Healing Ointment: A

Formulation of Hypericum Perforatum

Oil and Sage and Oregano Essential

Oils Based on Traditional Turkish

knowledge. J. Ethnopharmacol., 134(1),

89-96.

Trueman, S.L. and Wick, R.L.,(1996).

Fusarium Wilt of Herbs. Acta

Horticulturae, 426, 365-373.

Yanishlieva, N.V. and Marinova, E. (2006).

"Natural Antioxidants from Herbs and

Spices". European Journal of Lipid

Science and Technology, Pokorny J., 108, 776-793.

Żegarska, Z., Ryszard Rafałowski, R.,

Pegg, R. B., Magdalena Karamać, M. and Kosińska, A.(2009). "Antioxidant activity and free radical-scavenging capacity of ethanolic extracts of thyme, oregano, and marjoram". European Journal Lipid Science and Technology, 111(11), 1111-1117. 